\title{
Pengaruh Perlakuan Pemangkasan Dan Pemberian Pupuk Solid Terhadap Pertumbuhan Dan Produksi Tanaman Kedelai (Glycine max L. Merril)
}

\section{Effect of Trimming and Giving Solid Fertilizer Treatment on Growth and Production of Soybean Plants (Glycine max L. Merril)}

\author{
Mahdalena $^{1}$, Abdul Rofik ${ }^{1}$, Tiara Sartika Sari ${ }^{2}$ \\ ${ }^{1}$ Tenaga Pendidik Program Studi Agroteknologi, Fakultas Pertanian, Universitas Widya Gama Mahakam \\ Jl. KH. Wahid Hasyim, Sempaja, Samarinda, Kalimantan Timur, Indonesia \\ ${ }^{2}$ Tenaga Kependidikan Program Studi Agroteknologi, Fakultas Pertanian, Universitas Widya Gama Mahakam \\ Jl. KH. Wahid Hasyim, Sempaja, Samarinda, Kalimantan Timur, Indonesia \\ emailmahda.amin@yahoo.com, birudaun83@gmail.com, tiarasartikasari@yahoo.com
}

Diterima : 21 Agustus 2018 Disetujui : 12 Oktober 2018

\begin{abstract}
Soybean is an important food crop after rice and corn. Soybean production in East Kalimantan based on the 2014 forecast rate is estimated at 1,263 tons of dry seeds. Compared to 2013 production (ATAP 2013) there was a decrease of 139 tons (9.91\%) (BPS, 2014). The low productivity is because the technique of managing soybean plants is still not optimal. Efforts to increase soybean productivity can be done by conducting intensive cultivation techniques. One of the cultivation techniques that can be done is by technical methods, namely crop trimming and intensive agricultural cultivation can be done in various ways including fertilization. The study was carried out for 5 months, namely from January to May 2018. The research site was on experimental land owned by the Faculty of Agriculture, Widya Gama Mahakam Samarinda. This study used a Randomized Block Design (RBD) with a $2 \times 3$ factorial experiment consisting of 3 replications. The first factor is Pruning which consists of 2 levels: namely p0 (without pruning), pl (vegetative phase V4 pruning). The second factor is the dose of Solid fertilizer consists of 3 levels, namely $s 0$ (without fertilization), s1 (5 kg / plot), s2 (10 kg / plot). The results showed that the pruning $(P)$ treatment had a significant effect on the parameters of the number of productive branches and had no significant effect on height, flowering age, number of pods, weight of 100 seeds, weight of crop seeds and weight of mapped seeds. While giving Solid $(S)$ fertilizer does not significantly affect all parameters. But the interaction of the treatment of pruning and giving Solid (PS) significantly affected the parameters of the number of productive branches.
\end{abstract}

Keywords: Soybean, Solid, Pruning

\section{PENDAHULUAN}

Kedelai merupakan tanaman pangan penting setelah padi dan jagung. Produksi kedelai di Kalimantan Timur berdasarkan angka ramalan tahun 2014 diperkirakan sebesar 1.263 ton biji kering. Dibandingkan produksi tahun 2013 (ATAP 2013) terjadi penurunan sebaanyak 139 ton $(9,91 \%)$ (BPS, 2014).

Menurut Rukmana dan Herdi (2014). Produktifitas kedelai ditingkat petani rata-rata mencapai 1,29 ton/ha dengan potensi genetik tanaman yang masih cukup tinggi, yakni sebesar $>2$ ton/ha. Rendahnya produktifitas tersebut karena sebagian besar petani belum menggunakan benih unggul dan teknik pengelolaan tanaman kacang kedelai masih belum optimal.

Upaya peningkatan produktifitas kedelai dapat dilakukan dengan melakukan pengelolaan teknik budidaya tanaman secara intensif. Salah satu teknik budidaya yang dapat dilakukan adalah dengan metode teknis yaitu pemangkasan tanaman.

Pemangkasan adalah suatu tindakan membuang sebagian dari tanaman dengan maksud untuk menumbuhkan atau merangsang pembungaan dan pembuahan ke arah yang dikehendaki (Badan Litbang Pertanian, 2005).

Menurut Wahyudi, dkk (2008) Pada prinsipnya tujuan dari pemangkasan tanaman adalah mencegah tanaman kehilangan nutrisi pada fase vegetatifnya (pembentukan daun atau tunas) maupun pada fase generatif (pembentukan bunga dan buah)

Pada fase vegetatif pada ujung kuncup (kuncup terminal) terdapat dominasi apikal yang dapat menghambat pertumbuhan kuncup 
lateral yang akan membentuk cabang. Hal ini sesuai dengan pendapat oleh Tjitrosomo, dkk (2010) homon tumbuh pada umumnya mendorong pertumbuhan tetapi pada keadaan tertentu dapat menghambat perkembangan. Penghambatan pertumbuhan diduga terjadi pada dominasi apikal, pengendaliannya oleh kuncup lateral, yaitu menghambat atau mencegah pertumbuhan kuncup-kuncup tersebut.

Hal ini disebabkan oleh hormon tumbuh dari ujung berpengaruh pada tenunan transport dalam hal pengangkutan bahan makanan ke ujung dan menjauhi kuncup lateral. Dengan menghilangkan ujung yang tumbuh, hilang juga pengaruh yang direktif. Maka jumlah makanan yang "normal" akan menuju kuncup lateral sehingga akan tumbuh lebih cepat (Tjitrosomo, dkk 2010). Adanya dominasi apikal menyebabkan proses pengangkutan unsur hara ke bagian tunas lateral yang akan membentuk cabang terhambat.

Dari hasil penelitian Pane (2013) Perlakuan pemangkasan berpengaruh nyata menekan tinggi tanaman 5-6 minggu setelah tanam, meningkatkan total luas daun, diameter batang dan rasio tajuk- akar dengan perlakuan terbaik P1 ( pemangkasan fase V5).

Oleh karena itu pada tanaman kedelai perlu dilakukan pemangkasan pada fase vegetatif dan generatif untuk meningkatkan produktifitas kedelai melalui pembentukan cabang, bunga dan buah, hal ini sesuai dengan hasil penelitian Zamriyetti dan Rambe (2006) pemangkasan pada fase vegetatif dapat meningkatkan jumlah cabang primer dan pemangkasan pada fase generatif dapat meningkatkan bobot 100 biji dan berat biji kering per sampel.

Selain dengan pemangkasan, budidaya pertanian intensif dapat dilakukan dengan berbagai cara diantaranya dengan melakukan pemupukan. Untuk meningkatkan produksi tanaman kedelai diperlukan pemberian pupuk.

\section{BAHAN DAN METODE}

Penelitian ini dilakukan selama 5 bulan dimulai pada bulan Januari Sampai Mei di lokasi lahan praktek Fakultas Pertanian Universitas Widya Gama Mahakam Samarinda.Bahan yang digunakan dalam penelitian ini adalah benih tanaman kedelai varietas anjasmoro, Curater, Pupuk Solid dan Pupuk NPK, Alkohol. Penelitian ini menggunakan rancangan acak kelompok dengan percobaan faktorial $2 \times 3$ yang terdiri dari 3 ulangan. Faktor pertama adalah perlakuan pemangkasan yang terdiri dari 2 taraf yaitu : $p_{0}$ (tanpa pemangkasan) dan $\mathrm{p}_{1}$ (pemangkasan pada fase vegetatif (V4)
Pemupukan bertujuan untuk memelihara atau memperbaiki kesuburan tanah sehingga tanaman dapat tumbuh lebih cepat, subur dan sehat. Pemakaian pupuk anorganik selain dapat meningkatkan produksi namun juga meninggalkan residu yang bisa merusak lingkungan yang berakibat tidak baik. Sedangkan pupuk organik mengandung bahan penting yang dalam menciptakan kesuburan tanah baik fisik, kimia dan biologis, dimana berfungsi sebagai pemantap agregat tanah di samping sebagai sumber hara penting tanah dan tanaman.

Limbah pabrik Pengolahan Kelapa Sawit (PKS) dapat dimanfaatkan untuk meningkatkan kualitas bibit kelapa sawit seperti abu janjang kosong, tandan kosong sawit (TKS), solid dan lain-lain. Solid merupakan limbah padat dari hasil samping proses pengolahan tandan buah segar (TBS) di pabrik kelapa sawit menjadi minyak mentah kelapa sawit atau Crude Palm Oil (CPO). Solid mentah memiliki bentuk dan konsistensi seperti ampas tahu, berwarna kecokelatan, berbau asam-asam manis, dan masih mengandung minyak CPO sekitar 1,5\% (Ruswendi, 2008).

Menurut Darmawati J.S, Nursamsi \& Abdul Rasid Siregar (2014) solid yang dihasilkan dari Pengolahan Minyak Sawit (PMS) mengandung unsur hara nitrogen, fosfor, kalium, magnesium, dan kalsium yang cukup tinggi sehingga dapat digunakan sebagai pupuk. Komponen utama limbah padat kelapa sawit ialah selulosa dan lignin, sehingga limbah ini disebut sebagai limbah lignoselulosa.

Berdasarkan uraian di atas maka perlu dilakukan penelitian untuk mengetahui Pengaruh Pemakasan pada fase vegetatif serta pemberian pupuk Solid untuk meningkatkan produksi tanaman kedelai.

Sedangkan faktor kedua adalah dosis pupuk Solid yang terdiri dari 3 taraf, yaitu : $\mathrm{s}_{0}(0$ $\mathrm{g} /$ petak $), \mathrm{s}_{1}\left(5 \mathrm{Kg}\right.$ solid/petak) dan $\mathrm{s}_{2}(10 \mathrm{~kg}$ solid/petak). Pelaksanaan penelitian meliputi ; menyediaan benih, persiapan lahan, penanaman benih, pemupukan, pemangkasan, pemeriksaan (penyiraman, penyulaman dan penjarangan, penyiangan, pengendalian hama dan penyakit) dan panen. Paramaeter yang diambil ; tinggi tanaman, jumlah cabang produktif, jumlah polong per tanaman, jumlah biji per tanaman dan berat biji per 100 biji. Data hasil pengamatan dan pengukuran dianalisis dengan menggunakan analisis sidik ragam, apabila berpengaruh nyata akan dilanjutkan dengan menggunakan Uji BNT dengan taraf 5\%. 


\section{HASIL DAN PEMBAHASAN}

\section{Pengaruh Perlakuan Pemangkasan terhadap Produksi Tanaman Kedelai}

Berdasarkan hasil sidik ragam, pengaruh pemangkasan mempunyai pengaruh nyata terhadap parameter jumlah cabang produktif, namun tidak berpengaruh nyata terhadap parameter Tinggi Tanaman, jumlah polong, berat 100 biji dan berat biji pertanaman.

Perlakuan pemangkasan tidak berpengaruh nyata terhadap parameter Tinggi Tanaman, jumlah polong, berat 100 biji dan berat biji pertanaman. Namun secara berturut-turut perlakuan $\mathrm{p} 1$ menghasilkan hasil yang tertinggi yaitu 147.07 polong/tanaman, $14.88 \mathrm{~g}$ berat 100 biji dan $33.51 \mathrm{~g}$ berat biji/tanaman. Hal ini sesuai dengan pendapat Tjitrosomo, dkk (2010) hormon tumbuh pada umumnya mendorong pertumbuhan tetapi pada keadaan tertentu dapat menghambat perkembangan. Penghambatan pertumbuhan diduga terjadi pada dominasi apikal, pengendaliannya oleh kuncup terminal terhadap pertumbuhan kuncup lateral, yaitu menghambat atau mencegah pertumbuhan kuncup-kuncup tersebut. Dengan menghilangkan ujung yang tumbuh, hilang juga pengaruh yang direktif sehingga jumlah makanan yang normal akan menuju ke kuncup lateral sehingga akan tumbuh lebih cepat.

Pemangkasan pada pucuk batang utama diasumsikan dapat menekan pertumbuhan tunas apikal sehingga menekan tinggi tanaman, merangsang atau meningkatkan pertumbuhan cabang produktif yang ditunjukan melalui peningkatan cabang-cabang produktif sehingga menghasilkan peningkatan hasil produksi yang lebih tinggi.

Menurut Esrita (2012) Jumlah cabang merupakan salah satu karakter penunjang produksi biji karena berpengaruh terhadap jumlah buku subur, jumlah buku total, jumlah polong isi, jumlah polong per tanaman dan jumlah biji. Jumlah cabang pada tanaman kedelai mempengaruhi jumlah polongnya, karena cabang yang banyak mempunyai jumlah buku yang banyak, dan masing-masing buku dapat menghasilkan bunga yang pada akhirnya dapat membentuk polong.

\section{Pengaruh Perlakuan Pemberian Pupuk Solid terhadap Produksi Tanaman Kedelai}

Berdasarkan hasil sidik ragam perlakuan pemberian pupuk Solid (S) tidak berpengaruh nyata terhadap parameter tinggi tanaman, jumlah polong, berat 100 biji, Jumlah cabang dan berat biji pertanaman. Hal ini diduga karena unsur hara di dalam tanah tidak tersedia untuk tanaman, terutama untuk mendukung pertumbuhan tinggi tanaman, jumlah polong, berat 100 biji, Jumlah cabang dan berat biji pertanaman. Hal ini dapat dilihat dari hasil analisis kimia menunjukkan kandungan $\mathrm{P}$ total hanya sebesar $0.098 \%$, kandungan $\mathrm{N} 2,226 \%$, K 0,11\% dan kandungaan karbon (c) 20,72\% yang berarti pupuk terdebut belum terdekomposisi dengan baik sehingga belum mampu memenuhi kebutuhan unsur hara terhadap tanaman.

\section{Pengaruh Kombinasi Perlakuan Pemangkasan dan Pemberian Pupuk $P$ Terhadap Produksi Tanaman Kedelai.}

Berdasarkan hasil sidik ragam interaksi perlakuan pemangasan dan pemberian pupuk solid (S) tidak berpengaruh nyata terhadap seluruh parameter yang diamati hal ini diduga perlakuan pemangkasan dan pemberian pupuk solid berjalan masing-masing sehingga tidak memberikan pengaruh yang nyata.

\section{KESIMPULAN}

1. Perlakuan pemangkasan tanaman kedelai (Glycine $\max$ (L.) Merill) mempunyai pengaruh nyata terhadap parameter jumlah cabang produktif (fase vegetatif), namun tidak berpengaruh nyata terhadap parameter tinggi tanaman, jumlah polong, berat 100 biji, berat biji pertanaman.

2. Pemberian pupuk Solid tidak berpengaruh nyata terhadap parameter tinggi tanaman, jumlah polong, berat 100 biji,dan berat biji pertanaman.

3. Interaksi perlakuan pemangkasan dan pemberian pupuk Solid tidak berpengaruh nyata terhadap seluruh parameter yang diamati.

\section{UCAPAN TERIMA KASIH}

Terima kasih kepada Universitas Widya Gama Mahakam yang telah membiayai penelitian ini .

\section{DAFTAR PUSTAKA}

Adisarwanto, T. 2014. Kedelai Tropika Produktivitas 3 ton/ha. Penebar Swadaya. Jakarta. 
Adisarwanto, T. 2014. Kedelai. Penebar Swadaya. Jakarta.

Badan Penelitian dan Pengembangan Pertanian. 2005. Pemangkasan Pada Tanaman Jeruk. Bogor. Badan Litbang Pertanian.

Badan Perencanaan dan Pembangunan Daerah Kota Samarinda. Potret Kota Samarinda, keadaan Geografis dan Iklim. Samarinda. Bappeda Kota Samarinda.

Badan Pusat Statistik. 2014. Produksi Padi, Jagung dan Kedelai di Kalimantan Timur. Kalimantan Timur. BPS.

Badrudin, U., Syakiroh, J., dan Ari, S. 2008. Upaya Peningkatan Produksi mentimun (Cucumis sativus L) Melalui Waktu Pemangkasan Pucuk dan Pemberian Pupuk Posfat. Fakultas Pertanian Universitas Pekalongan. Jawa Tengah.

Bimasri, J. 2012. Pengaruh Waktu dan Panjang Pemangkasan Ruas Batang Terhadap Pertumbuhan dan Produksi Tanaman Kedelai (Glicine max). Jurnal Agro Silampari Vol. 2 No. 1 Tahun 2012 ISSN :2088-866X. Fakultas Pertanian Universitas Musi Rawas. Palembang.

Hanafiah, Kemas Ali. 2005. Rancangan Percobaan. PT. Raja Grafindo. Jakarta.

Hardjowigeno, S. 2007. Ilmu Tanah. Akademika Presindo. Jakarta.

Jumin, H. B. 2005. Dasar-Dasar Agronomi. Raja Grafindo Persada. Jakarta.

Pahan, I. 2008. Panduan Lengkap Kelapa Sawit: Manajemen Agribisnis dari Hulu hingga Hilir. Penebar Swadaya. Jakarta.

Pane, I, S., Lisa, M., dan Irmansyah, T. 2013. Respons Pertumbuhan Kedelai Terhadap Pemangkasan dan Pemberian Kompos TKKS Pada Lahan Ternaungi. Jurnal Online Agroekoteknologi Vol.2 No.1 : 393-
401. Desember 2013. ISSN No.2337-6597. Fakultas pertanian USU. Medan.

Petrokimia Gresik. 2013. Pupuk SP 36 \& ZK. Gresik.

Rukmana, R., dan Herdi, Y. 2014. Budidaya dan Pengolahan Hasil Kacang Kedelai Unggul. Nuansa Aulia. Bandung.

Sudarmo, AS.,1997. Mengenal dan Merawat Tanaman Hias Ruangan.

Kanisius. Yogyakarta.

Thoyyibah, S., Sumadi, dan Anna, N. 2014. Pengaruh Dosis Pupuk Fosfat Terhadap Pertumbuhan, Komponen Hasil, Hasil dan Kualitas Benih Dua Varietas Kedelai (Glycine $\max$ (L.) Merill) Pada Inceptisol Jatinanggor. Fakultas Pertanian Universitas Padjajaran. Bandung.

Tjitrosomo, S, S. 2010. Botani Umum 1. Angkasa. Bandung.

Utomo, N. U dan Widjaja. 2005. Limbah Padat Pengolahan Minyak Sawit Sebagai Sumber Nutrisi Ternak Ruminansia. Balai Pengkajian Teknologi Pertanian Kalimantan Tengah.http://www.pustakadeptan.go.id/publikasi/p3231044.pdf.

Wahyudi, T., T.R. Panggabean dan Pujiyanto. 2008. Panduan Lengkap Kakao. Penebar Swadaya. Jakarta.

Wuryaningsih, S. Sutater, T. dan Sutomo. 1997. Pengaruh Dosis dan Frekwensi Pemberian Pupuk Kalium Serta Persentase Air Tersedia Terhadap Tanaman Melati. Pusat Penelitian dan Pengembangan Hortikultura, Jakarta. Jurnal Hortikultura I (3). Hal 781787.

Zamriyetti dan S. Rambe. 2002. Pertumbuhan dan Produksi Tanaman Kedelai (Glycine max L. Merrill) Pada Berbagai Konsentrasi Pupuk Daun Grow More dan Waktu Pemangkasan. Fakultas Pertanian UNPAD. Medan. 